\title{
Pendeteksian Malware pada Lingkungan Aplikasi Web dengan Kategorisasi Dokumen
}

\author{
Fransiskus Gusti Ngurah Dwika Setiawan, Royyana Muslim Ijtihadi, dan Hudan Studiawan \\ Jurusan Teknik Informatika, Fakultas Teknologi Informasi Institut Teknologi Sepuluh Nopember (ITS) \\ Jl. Arief Rahman Hakim, Surabaya 60111 Indonesia \\ e-mail: fgn.dwikasetiawan@gmail.com,roy@if.its.ac.id, hudan@if.its.ac.id
}

\begin{abstract}
Abstrak-Jumlah aplikasi berbasis web semakin bertambah seiring dengan perkembangan teknologi informasi. Dengan bertambahnya jumlah aplikasi web, serangan-serangan yang dilakukan terhadap aplikasi-aplikasi web tersebut juga meningkat. Salah satu jenis serangan yang marak dilakukan terhadap aplikasi web adalah penyisipan malware seperti web shell yang dapat memberikan akses bebas terhadap komputer server kepada penyerang. Dalam makalah ini, dijelaskan implementasi aplikasi yang menerapkan teknik kategorisasi dokumen untuk mendeteksi malware atau kode malicious khususnya jenis web shell dengan teknik kategorisasi dokumen. Proses kategorisasi dokumen meliputi praproses dan tokenisasi kode sumber, pembuatan model classifier Multinomial Naive Bayes dan Decision Tree, dan klasifikasi dokumen menggunakan classifier yang telah dibuat. Uji coba yang dilakukan terhadap 718 file kode sumber PHP menghasilkan tingkat precision dari $72 \%$ hingga $83 \%$ dan recall $83 \%$ hingga $97 \%$.
\end{abstract}

Kata Kunci-aplikasi web, deteksi malware, kategorisasi dokumen

\section{PENDAHULUAN}

$\mathrm{S}$ EIRING berkembangnya teknologi informasi, jumlah aplikasi web yang tersebar di internet semakin meningkat. Salah satu hal yang memacu peningkatan tersebut adalah semakin maraknya perangkat-perangkat lunak yang memudahkan seseorang dalam membuat aplikasi web. Salah satu contoh perangkat lunak yang dapat mempermudah pembuatan aplikasi web tersebut adalah sistem manajemen konten Wordpress. Berkat perangkat-perangkat lunak tersebut, seseorang tidak perlu memiliki pengetahuan teknis yang tinggi untuk dapat membuat aplikasi web. Namun sayangnya beberapa pemilik aplikasi web tidak begitu memperhatikan atau paham aspek-aspek keamanan aplikasi dan jaringan. Hal ini memicu terjadinya serangan-serangan digital yang dilakukan terhadap aplikasi-aplikasi web yang tidak terproteksi.

Salah satu bentuk serangan yang dapat dilakukan adalah penyisipan file-file berbahaya atau malicious ke komputer penyedia aplikasi web. Contoh dari file berbahaya yang dapat disisipkan adalah skrip web shell. Apabila berhasil diunggah, skrip web shell dapat memberikan akses shell tidak sah kepada pengunggah skrip secara jarak jauh. Hal ini berpotensi merusak aplikasi web dan juga komputer server yang menyediakan aplikasi web tersebut.

Efek dari serangan berupa penyisipan file malicious dapat diatasi dengan memindai file-file pada aplikasi web untuk mencari dan menghapus file-file yang terdeteksi malicious. Salah satu metode pendeteksian file malicious yang pernah dilakukan adalah dengan menggunakan kategorisasi dokumen. Kategorisasi dokumen adalah suatu teknik untuk memetakan sebuah dokumen ke dalam satu atau beberapa kategori dengan menggunakan teknik machine learning. A. Shabtai et al. dalam penelitiannya[1] melakukan pendeteksian kode malicious dalam file-file biner dengan melakukan kategorisasi terhadap pola OpCode. OpCode adalah bagian dari instruksi bahasa mesin yang mendefinisikan operasi apa yang harus dilakukan.

Makalah ini membahas tentang penerapan teknik kategorisasi dokumen untuk mendeteksi malware di lingkungan aplikasi web. Makalah ini disusun dengan urutan sebagai berikut: pendahuluan, dasar teori, metode, perancangan sistem, uji coba dan evaluasi, kesimpulan, dan saran.

\section{DASAR TEORI}

\section{A. Kategorisasi Dokumen}

Kategorisasi teks adalah pekerjaan pemberian label kategori kepada sebuah dokumen teks [2]. Label kategori tersebut diambil dari kumpulan kategori-kategori yang telah ditentukan sebelumnya. Secara formal kategorisasi teks dapat didefinisikan sebagai kegiatan pemberian nilai Boolean true atau false kepada setiap pasangan dokumen-kategori $\left\langle d_{i}, c_{j}\right\rangle \in D \times C$, dengan $\boldsymbol{D}$ adalah himpunan semua dokumen dan $\boldsymbol{C}$ adalah himpunan semua kategori. Nilai true menyatakan bahwa dokumen $\boldsymbol{d}_{\boldsymbol{i}}$ termasuk dalam kelas $\boldsymbol{c}_{\boldsymbol{j}}$, sebaliknya nilai false menyatakan bahwa dokumen $\boldsymbol{d}_{i}$ tidak termasuk dalam kelas $\boldsymbol{c}$.

Untuk dapat melakukan kategorisasi dokumen secara otomatis, perlu diketahui fungsi target $\phi^{\prime}: D \times C \rightarrow\{T, F\}$ yang mendeskripsikan bagaimana dokumen seharusnya diklasifikasi. Fungsi target tidak dapat diketahui secara pasti. Oleh karena itu, teknik machine learning diterapkan untuk mencari pendekatan fungsi target.

\section{B. Vector Space Model}

Vector Space Model adalah representasi matematis dari dokumen teks. Sebuah dokumen $\boldsymbol{d}$ yang di dalamnya terdapat $\boldsymbol{n}$ kata / term unik $\boldsymbol{t}_{\mathbf{1}}, \boldsymbol{t}_{\mathbf{2}}, \boldsymbol{t}_{\mathbf{3}}, \ldots, \boldsymbol{t}_{\mathbf{n}}$ memiliki representasi vektor ( $\boldsymbol{w}_{\mathbf{1}}$, $\left.w_{2}, w_{3}, \ldots, w_{n}\right)$, dengan $w_{i}$ adalah bobot atau nilai dari term $\boldsymbol{t}_{\boldsymbol{i}}$ untuk dokumen $\boldsymbol{d}$. Representasi vektor ini biasa digunakan dalam sistem temu kembali informasi, namun dapat juga digunakan untuk kasus kategorisasi dokumen [2]. 
Dalam kasus kategorisasi dokumen, classifier menerima bentuk vektor dari dokumen untuk diklasifikasi. Ada banyak jenis bobot suatu term untuk sebuah dokumen. Beberapa contoh jenis bobot tersebut adalah bobot biner ( 0 atau 1$)$, bobot TF (Term Frequency), dan bobot TF-IDF (Term FrequencyInverse Document Frequency). Jenis bobot yang dipakai tergantung dari kasus penggunaan.

\section{Term Frequency dan TF-IDF}

Term Frequency dan TF-IDF (term frequency - inverse document frequency) adalah contoh jenis pembobotan term dalam kategorisasi dokumen dan temu kembali informasi [3]. Term frequency atau TF dari suatu term $\boldsymbol{t}$ untuk dokumen $\boldsymbol{d}$ didefinisikan sebagai jumlah kemunculan $\boldsymbol{t}$ dalam $\boldsymbol{d}$. Semakin panjang suatu dokumen, maka nilai TF masing-masing termnya cenderung semakin besar. Untuk mengurangi efek ini, seringkali digunakan bentuk lain dari pembobotan TF, seperti (1).

$$
T F_{t, d}^{\prime}= \begin{cases}1+\log _{10} T F_{t, d} & T F_{t, d}>0 \\ 0 & T F_{t, d}=0\end{cases}
$$

$\boldsymbol{T F}_{\boldsymbol{t}, \boldsymbol{d}}$ adalah nilai TF untuk term $\boldsymbol{t}$ dan dokumen $\boldsymbol{d}$, sedangkan $\boldsymbol{T F}_{\boldsymbol{t}, \boldsymbol{d}}$ adalah nilai $\boldsymbol{T F}_{\boldsymbol{t}, \boldsymbol{d}}$ dalam bentuk logaritma. Dengan menggunakan logaritma, dokumen panjang tidak akan memiliki bobot-bobot yang jauh lebih besar daripada dokumen pendek.

Selain pembobotan dengan TF, terdapat juga pembobotan dengan TF-IDF (Term Frequency - Inverse Document Frequency). Pembobotan TF-IDF mempertimbangkan seberapa unik suatu term dalam kumpulan dokumen. Pembobotan ini mengasumsikan bahwa suatu term yang muncul di banyak dokumen adalah term yang tidak penting. Semakin unik suatu term, maka term tersebut dianggap penting. Contohnya dalam kumpulan dokumen berbahasa Indonesia, term (kata) "di", "dan", "ke", "yang", "atau", dan "dan" muncul di banyak dokumen. Kata-kata tersebut tidak berkontribusi banyak dalam sistem pencarian dokumen atau kategorisasi dokumen. Oleh karena itu kata-kata tersebut harus diberi bobot yang lebih rendah daripada kata-kata yang lebih unik. Dari situ muncul persamaan pembobotan TF-IDF seperti yang ditunjukkan pada (2).

$$
\text { TFIDF } F_{t, d}^{\prime}= \begin{cases}1+\log _{10} T F_{t, d} \times N / d f_{t} & T F_{t, d}>0 \\ 0 & T F_{t, d}=0\end{cases}
$$

$\boldsymbol{N}$ adalah jumlah dokumen, dan $\boldsymbol{d} \boldsymbol{f}_{\mathrm{t}}$ adalah document frequency dari term $\boldsymbol{t}$, yakni jumlah dokumen yang mengandung term $\boldsymbol{t}$.

\section{Naive Bayes}

Naive Bayes merupakan salah satu algoritma machine learning. Algoritma ini menerapkan teorema Bayes untuk mengklasifikasi suatu data dengan mengasumsikan bahwa fitur-fitur dalam data tersebut tidak bergantung oleh satu sama lainnya (independen) [4]. Teorema Bayes menyatakan bahwa peluang dari sebuah sampel $\boldsymbol{d}=\left(\boldsymbol{x}_{1}, \boldsymbol{x}_{2}, \ldots, \boldsymbol{x}_{\boldsymbol{n}}\right)$ termasuk dalam sebuah kelas $\boldsymbol{c}$ adalah:

$$
p(c \mid d)=\frac{p(d \mid c) p(c)}{p(d)}
$$

Dengan mengasumsikan bahwa masing-masing fitur pada $\boldsymbol{d}$ tidak bergantung satu sama lain, maka persamaan (3) menjadi:

$$
\begin{aligned}
p(c \mid d) & =\frac{p(c)}{p(d)} \prod_{i=1}^{n} p\left(x_{i} \mid c\right) \\
& \propto p(c) \prod_{i=1}^{n} p\left(x_{i} \mid c\right)
\end{aligned}
$$

Dokumen $\boldsymbol{d}$ termasuk dalam kelas dengan nilai $\boldsymbol{p}(\boldsymbol{c} \mid \boldsymbol{d})$ tertinggi untuk $\boldsymbol{c} \in \boldsymbol{C}$ dengan $\boldsymbol{C}$ adalah himpunan semua kelas yang mungkin untuk dokumen $\boldsymbol{d}$.

Salah satu bentuk dari algoritma Naive Bayes untuk mengklasifikasi dokumen adalah Multinomial Naive Bayes [5]. Dalam penerapan Multinomial Naive Bayes untuk klasifikasi dokumen, nilai $\boldsymbol{x}_{\boldsymbol{i}}, \boldsymbol{i}=1 \ldots \boldsymbol{n}$ merupakan nilai numerik, maka dari itu $\boldsymbol{p}(\boldsymbol{c} \mid \boldsymbol{d})$ didefinisikan seperti pada (5).

$$
p(c \mid d) \propto p(c) \prod_{i=1}^{n} p^{x_{i}}\left(x_{i} \mid c\right)
$$

Nilai $\boldsymbol{p}(\boldsymbol{x} \mid \boldsymbol{c})$ merupakan frekuensi relatif term $\boldsymbol{x}$ dari dokumen-dokumen dalam kelas $\boldsymbol{c}$. Nilai tersebut didefinisikan seperti pada (6).

$$
p(x \mid c)=\frac{T_{x, c}}{\sum_{x^{\prime} \in X} T_{x^{\prime}, c}}
$$

Dengan $\boldsymbol{T}_{\boldsymbol{x}, \boldsymbol{c}}$ adalah jumlah nilai TF atau TF-IDF dari term $\boldsymbol{x}$ dari semua dokumen dalam kelas $\boldsymbol{c}$, dan $\boldsymbol{X}$ adalah himpunan seluruh term.

Terkadang dalam suatu kelas tidak terdapat sama sekali term $\boldsymbol{x}$. Hal ini menyebabkan nilai $\boldsymbol{T}_{\boldsymbol{x}}$ menjadi nol. Apabila nilai $\boldsymbol{T}_{\boldsymbol{x}}=$ 0 dibiarkan, maka nilai $\boldsymbol{p}(\boldsymbol{x} \mid \boldsymbol{c})$ pasti nol juga. Untuk mencegah hal ini, biasanya nilai $\boldsymbol{T}_{\boldsymbol{x}}$ ditambah satu, sehingga (6) akan menjadi seperti (7).

$$
p(x \mid c)=\frac{T_{x, c}+1}{\sum_{x^{\prime} \in X} T_{x^{\prime}, c}+1}
$$

Nilai-nilai $p(c), \log p(c), p\left(x_{i} \mid c\right), \log p\left(x_{i} \mid c\right)$ untuk masing-masing kelas dihitung pada tahap pembangunan model atau training. Nilai-nilai tersebut dapat disimpan untuk mengklasifikasi data-data baru.

\section{E. Decision Tree}

Decision Tree adalah salah satu jenis algoritma machine learning yang lazim digunakan untuk klasifikasi maupun regresi [6]. Terdapat beberapa jenis algoritma Decision Tree. Beberapa di antaranya adalah: ID3, C4.5, dan CART.

Tujuan dari algoritma Decision Tree secara umum adalah memprediksi nilai dari variabel target $\boldsymbol{y}$ dari sampel $\boldsymbol{x}$ yang memiliki $n$ fitur $\boldsymbol{x}_{1}, \boldsymbol{x}_{2}, \ldots, \boldsymbol{x}_{\boldsymbol{n}}$. Hal ini dilakukan dengan membuat sebuah tree. Pada algoritma CART, jenis tree yang dibuat adalah binary tree [7].

Masing-masing node internal pada tree merepresentasikan suatu dataset. Dataset tersebut kemudian dipecah ke dalam dua node baru di sebelah kanan dan kiri node sebelumnya. Pemecahan dataset tersebut dilakukan berdasarkan pengecekan nilai dari sebuah fitur $\boldsymbol{x}_{\boldsymbol{j}}$. Apabila sampel $\boldsymbol{x}^{\boldsymbol{i}}$ memiliki fitur $\boldsymbol{x}_{\boldsymbol{j}} \boldsymbol{j}$ yang bernilai kurang dari sebuah nilai $s_{j}$, maka sampel tersebut masuk ke node cabang kiri dari node sekarang. Apabila 
sebaliknya, maka sampel tersebut masuk ke dalam node cabang kanan dari node sekarang. Proses tersebut dilakukan secara rekursif hingga terbentuk leaf. Sebuah node menjadi leaf apabila seluruh sampel dalam datasetnya memiliki nilai variabel target $y$ yang sama, atau apabila jumlah sampel dalam datasetnya kurang dari nilai threshold tertentu.

Fitur yang dicek dan nilai $s_{j}$ pada masing-masing node ditentukan dengan menggunakan aturan yang disebut splitting rule. Salah satu splitting rule yang lazim digunakan dalam algoritma CART adalah gini splitting rule. Gini splitting rule menentukan fitur yang digunakan untuk memecah dataset dengan cara menghitung perubahan nilai gini impurity. Pada kasus klasifikasi, nilai gini impurity untuk suatu node $\boldsymbol{n}$ dapat didefinisikan seperti pada (8).

$$
I(n)=\sum_{y \in Y} f_{n, y}\left(1-f_{n, y}\right)
$$

Dengan $\mathbf{I}(\boldsymbol{n})$ adalah nilai gini impurity dari node $\boldsymbol{n}, \boldsymbol{Y}$ adalah kumpulan nilai-nilai yang mungkin dari variabel target, $\boldsymbol{f}_{\boldsymbol{n}, \boldsymbol{y}}$ adalah perbandingan jumlah sampel dengan kelas $y$ pada node $\boldsymbol{n}$ dengan jumlah semua sampel pada node $\boldsymbol{n}$.

Perubahan nilai gini impurity dapat dihitung seperti pada (9).

$$
\Delta I(n)=I(n)-I\left(n_{l}\right)-I\left(n_{r}\right)
$$

$\Delta \boldsymbol{I}(\boldsymbol{n})$ adalah perubahan nilai gini impurity, $\boldsymbol{I}\left(\boldsymbol{n}_{\boldsymbol{\prime}}\right)$ adalah nilai gini impurity untuk node cabang kiri, dan $\boldsymbol{I}\left(\boldsymbol{n}_{\boldsymbol{r}}\right)$ adalah nilai gini impurity untuk node cabang kanan. Nilai $\Delta \boldsymbol{I}(\boldsymbol{n})$ dihitung untuk tiap-tiap fitur yang ada. Fitur dan nilai pemecah $\boldsymbol{s}_{j}$ yang dapat menghasilkan pemecahan dataset dengan nilai $\Delta \boldsymbol{I}(\boldsymbol{n})$ terbesar akan digunakan untuk memecah dataset pada node $\boldsymbol{n}$.

Data baru dapat diklasifikasi dengan cara melakukan pengecekan nilai fitur dari data tersebut sesuai dengan node -node pada model tree yang dibentuk, mulai dari node awal sampai leaf. Nilai kelas $\boldsymbol{y}$ untuk data baru tersebut adalah kelas dengan jumlah sampel terbanyak pada leaf yang dicapai.

\section{METODE}

Ada tiga jenis proses yang perlu dilakukan untuk dapat mengklasifikasi apakah suatu file malicious atau tidak. Proses-proses tersebut adalah: praproses, training, dan klasifikasi.

\section{A. Praproses}

Praproses bertujuan untuk mengambil potongan kode sumber PHP dari sebuah file, lalu melakukan tokenisasi terhadap potongan kode sumber tersebut. Kode sumber yang berupa sebuah string panjang akan dipecah menjadi kumpulan token-token. Token dalam konteks kode sumber PHP dapat berupa sebuah keyword, nama variabel, nama fungsi, konstanta, operator, tag PHP, dan sebagainya. Dari semua jenis-jenis token tersebut, yang akan digunakan dalam proses training dan klasifikasi adalah token nama variabel, nama fungsi, nama kelas, keyword eval dan echo, dan juga konstanta string. Untuk jenis token konstanta string, akan dilakukan pengelompokan seperti berikut:

1. String panjang (lebih dari nilai threshold tertentu) akan diubah menjadi token "LONG_NORMAL_STRING".
2. String dalam format base64 dengan panjang lebih dari nilai threshold tertentu akan diubah menjadi token "LONG_BASE64_STRING".

3. Token-token yang di dalamnya terdapat representasi karakter dalam bentuk heksadesimal (contoh: $\mid \mathrm{x} 8 \mathrm{~F})$ akan diubah menjadi token "STRING_WITH_HEX_LITERAL".

Pengelompokan berdasarkan bentuk ini dilakukan untuk mengurangi jumlah fitur dokumen.

Kumpulan token-token tersebut merupakan luaran dari tahap praproses. Luaran tersebut kemudian akan digunakan pada tahap training dan klasifikasi.

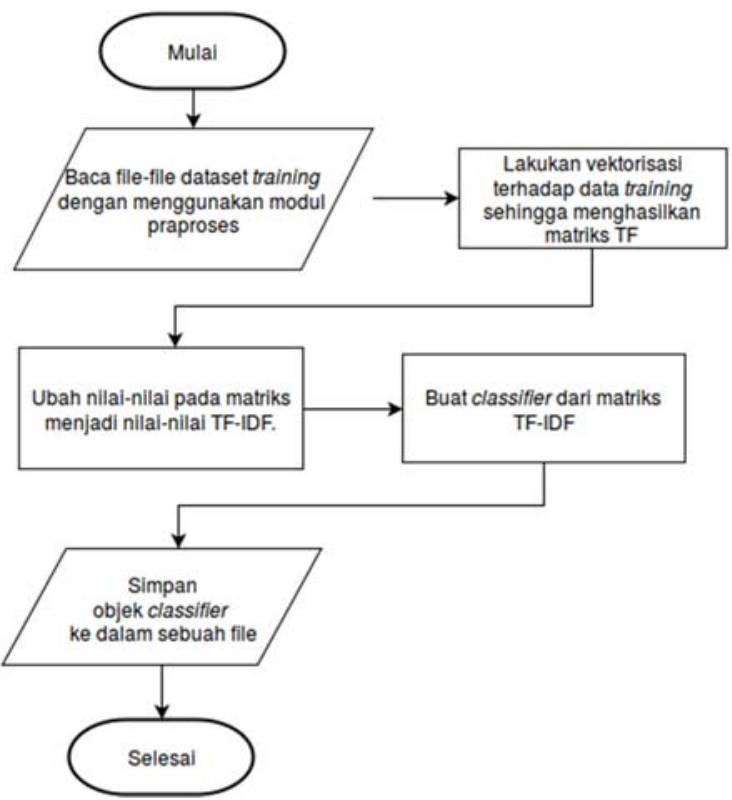

Gambar 1. Diagram alir dari proses training. Proses training menghasilkan objek classifier dari data belajar masukan

jenis token konstanta string, akan dilakukan pengelompokan seperti berikut:

1. String panjang (lebih dari nilai threshold tertentu) akan diubah menjadi token "LONG_NORMAL_STRING".

2. String dalam format base64 dengan panjang lebih dari nilai threshold tertentu akan diubah menjadi token "LONG_BASE64_STRING".

3. Token-token yang di dalamnya terdapat representasi karakter dalam bentuk heksadesimal (contoh: $\backslash \mathrm{x} 8 \mathrm{~F}$ ) akan diubah menjadi token "STRING_WITH_HEX_LITERAL".

Pengelompokan berdasarkan bentuk ini dilakukan untuk mengurangi jumlah fitur dokumen.

Kumpulan token-token tersebut merupakan luaran dari tahap praproses. Luaran tersebut kemudian akan digunakan pada tahap training dan klasifikasi.

\section{B. Training}

Proses training bertujuan untuk menghasilkan model-model classifier Multinomial Naive Bayes dan Decision Tree dari data masukan. Diagram alir untuk proses ini dapat dilihat pada Gambar 1.

Proses training menerima data masukan berupa data belajar yang merupakan kumpulan kode sumber - kode sumber yang telah teridentifikasi sebagai kode sumber malicious atau 
non-malicious. Sebelum menjadi masukan pada proses ini, data belajar tersebut akan dipraproses terlebih dahulu. Kemudian data tersebut akan diubah ke dalam bentuk vektor melalui proses vektorisasi. Proses vektorisasi menghasilkan matriks $\boldsymbol{M}$ berukuran $\boldsymbol{m} \times \boldsymbol{n}$, dengan $\boldsymbol{m}$ adalah jumlah dokumen dan $\boldsymbol{n}$ adalah jumlah token unik dari seluruh dokumen. Masing-masing baris pada $\boldsymbol{M}$ merepresentasikan sebuah dokumen, dan masing-masing kolomnya merepresentasikan sebuah token. Pada matriks $\boldsymbol{M}$, elemen $\boldsymbol{M}_{\boldsymbol{i}}$, j berisi jumlah kemunculan token ke-j pada dokumen ke-i. Nilai-nilai tersebut kemudian akan diubah menjadi nilai-nilai TF-IDF.

Setelah proses tokenisasi dan vektorisasi selesai, model-model classifier akan dibangun menggunakan algoritma machine learning. Algoritma machine learning yang digunakan dalam penelitian ini adalah Multinomial Naive Bayes dan Decision Tree. Objek-objek classifier yang dihasilkan akan disimpan masing-masing ke dalam sebuah file. File-file tersebut adalah luaran dari proses training dan akan digunakan dalam proses klasifikasi.

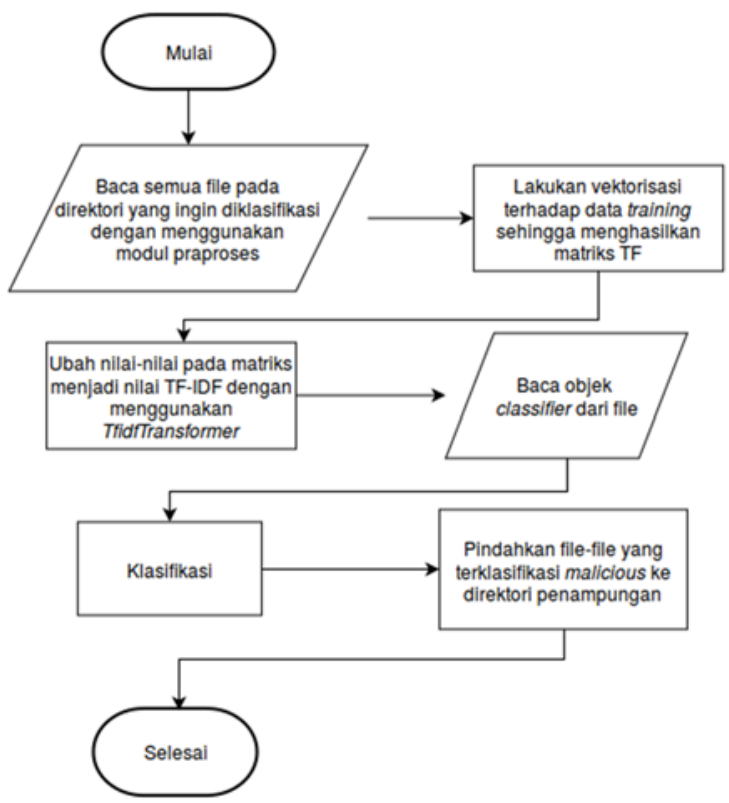

Gambar 2. Diagram alir dari proses klasifikasi. Proses ini menghasilkan prediksi-prediksi kategori untuk tiap-tiap file masukan dengan menggunakan objek-objek classifier hasil proses training.

\section{Klasifikasi}

Proses klasifikasi menerima file-file masukan dan objek-objek classifier hasil proses training. Hasil dari proses klasifikasi adalah kumpulan prediksi kategori dari masing-masing file masukan. Diagram alir proses klasifikasi dapat dilihat pada Gambar 2.

Proses klasifikasi dimulai dengan membaca file-file dari direktori yang telah ditentukan. File-file yang dibaca akan dipraproses terlebih dahulu. Kemudian akan dilakukan vektorisasi terhadap hasil praproses tersebut. Hasil vektorisasi berupa matriks $\boldsymbol{M}$ berukuran $\boldsymbol{m} \times \boldsymbol{n}$, dengan $\boldsymbol{m}$ adalah jumlah dokumen dan $\boldsymbol{n}$ adalah jumlah token unik dari seluruh dokumen. Nilai-nilai dari matriks $\boldsymbol{M}$ akan menjadi nilai TF-IDF. Matriks tersebut kemudian akan diklasifikasi dengan menggunakan model-model classifier yang telah dihasilkan oleh modul training.

\section{PERANCANGAN SISTEM}

Aplikasi akan dipasang dalam komputer server yang berisi aplikasi web target. Arsitektur dari implementasi ini dapat dilihat pada Gambar 3.

Implementasi dari aplikasi pendeteksi malware ini akan memiliki tiga modul, yakni modul praproses, modul training, dan modul klasifikasi. Modul praproses akan menyediakan fungsi yang dapat digunakan oleh modul lain untuk mempraproses dokumen.

Modul training berfungsi untuk menjalankan proses training dengan masukan berupa dataset training yang telah disediakan sebelumnya. Modul klasifikasi dapat menerima kumpulan file-file dan melakukan klasifikasi terhadap file-file tersebut dengan menggunakan objek-objek classifier hasil dari modul training. Pada Gambar 3, ditunjukkan bahwa modul klasifikasi akan menerima file-file dari aplikasi web untuk diklasifikasi.

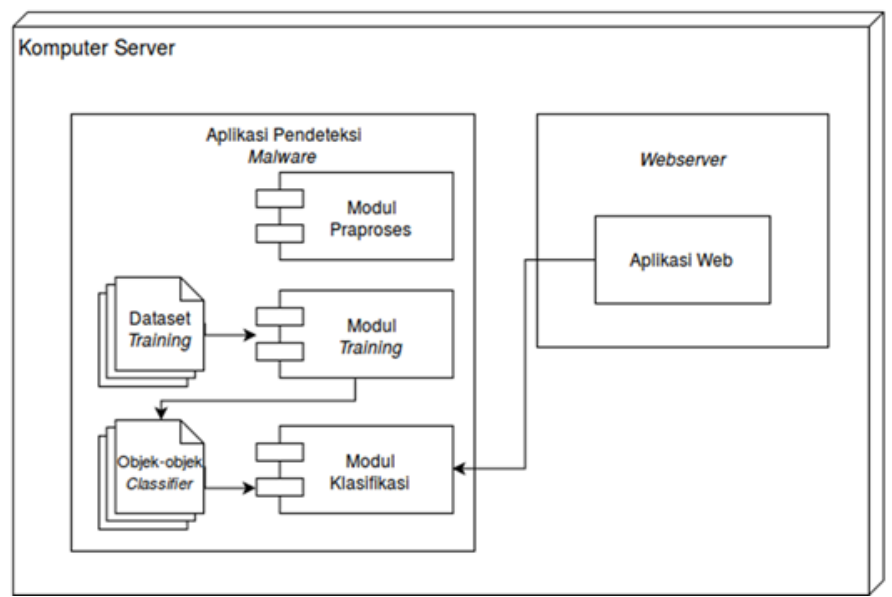

Gambar 3. Diagram arsitektur system. Di sini digambarkan lingkungan komputer server yang menyediakan sebuah aplikasi web. Aplikasi pendeteksi malware dipasang pada komputer tersebut, terpisah dari aplikasi web.

\section{UJI COBA DAN EVALUASI}

Penerapan teknik kategorisasi dokumen untuk pendeteksian malware yang telah diimplementasikan akan dievaluasi dengan menghitung nilai precision dan recall dari hasil uji coba klasifikasi terhadap dataset masukan. Nilai precision didefinisikan seperti pada (10).

$$
P=\frac{T P}{T P+F P}
$$

$\boldsymbol{P}$ adalah nilai precision, $\mathbf{T P}$ adalah jumlah true positive (jumlah file malicious yang terklasifikasi malicious), dan $\mathbf{F P}$ adalah jumlah false positive (jumlah file non-malicious yang terklasifikasi malicious). Nilai recall didefinisikan seperti pada (11).

$$
R=\frac{T P}{T P+F N}
$$

$\boldsymbol{R}$ adalah nilai recall, dan $\boldsymbol{F N}$ adalah jumlah false negative (jumlah file malicious yang terklasifikasi non-malicious). Uji coba dan perhitungan nilai precision dan recall akan dilakukan dalam beberapa skenario. 


\section{A. Skenario Uji Coba}

Ada dua jenis uji coba yang akan dilakukan: uji coba tahap training dan uji coba tahap testing. Masing-masing jenis uji coba tersebut dilakukan dalam dua skenario, masing-masingnya menggunakan classifier yang berbeda. Skenario - skenario tersebut dapat dilihat pada Tabel 1.

Pada uji coba tahap training, sebuah model classifier akan dibuat dari dataset training. Hasil model classifier tersebut akan diuji coba untuk mengklasifikasi kembali dataset training. Sedangkan pada uji coba tahap testing, dataset testing akan diklasifikasi dengan model classifier yang telah dibangun pada uji coba tahap training.

Tabel 1. Rincian skenario-skenario uji coba.

\begin{tabular}{|c|c|c|c|}
\hline No & Jenis Uji Coba & Dataset Masukan & Model Classifier \\
\hline 1 & $\begin{array}{l}\text { Uji coba tahap } \\
\text { training }\end{array}$ & Dataset training & $\begin{array}{l}\text { Multinomial Naive } \\
\text { Bayes }\end{array}$ \\
\hline 2 & $\begin{array}{l}\text { Uji coba tahap } \\
\text { training }\end{array}$ & Dataset training & Decision Tree \\
\hline 3 & $\begin{array}{l}\text { Uji coba tahap } \\
\text { testing }\end{array}$ & Dataset testing & $\begin{array}{l}\text { Multinomial } \\
\text { Bayes }\end{array}$ \\
\hline 4 & $\begin{array}{l}\text { Uji coba tahap } \\
\text { testing }\end{array}$ & Dataset testing & Decision Tree \\
\hline
\end{tabular}

\section{B. Deskripsi Data Uji Coba}

Ada dua jenis dataset yang akan digunakan untuk uji coba, yakni dataset training dan dataset testing. Dataset training terdiri dari 427 kode sumber PHP malicious dan 500 kode sumber PHP non-malicious, dan dataset testing terdiri dari 218 kode sumber PHP malicious dan 500 kode sumber PHP non-malicious. Dataset training akan digunakan dalam proses pembuatan model classifier dan juga uji coba tahap training. Sedangkan dataset testing akan digunakan untuk uji coba namun tidak dicantumkan dalam proses pembuatan model classifier seperti dataset training. Sampel kode non-malicious diambil dari contoh proyek Wordpress versi 4.6.1 dan versi 4.5.0, masing-masing sebanyak 500 file kode PHP. Sebanyak 544 file kode malicious diambil dari situs repositori GitHub, dan 101 file kode sumber malicious lainnya diambil dari komputer server web Informatika ITS.

\section{Hasil Uji Coba}

Berikut adalah hasil dari masing-masing skenario uji coba yang telah dijabarkan sebelumnya:

1) Hasil Skenario I: Uji coba tahap training dengan Multinomial Naive Bayes.

Hasil uji coba skenario pertama ditunjukkan oleh Tabel 2. Dari 427 file malicious, 362 file terklasifikasi dengan benar namun 65 lainnya terklasifikasi sebagai non-malicious. Sedangkan dari 500 file non-malicious, 493 file terklasifikasi dengan benar namun 7 lainnya terklasifikasi sebagai malicious. Nilai precision dari hasil di atas adalah 98,10\% (362/(362+7)) dan nilai recall-nya adalah $84,77 \%$ (362/427).

2) Hasil Skenario II: Uji coba tahap training dengan Decision Tree.

Hasil uji coba skenario kedua ditunjukkan oleh Tabel 3. Semua file malicious terklasifikasi dengan benar. Sedangkan dari 500 file non-malicious, 464 file terklasifikasi dengan benar tetapi 36 lainnya terklasifikasi sebagai malicious. Nilai precision dari hasil di atas adalah $92,22 \%(427 /(427+36))$ dan nilai recall-nya adalah $100 \%$ (427/427).

Tabel 2. Hasil klasifikasi dari dataset training dengan Multinomial Naive

\begin{tabular}{|c|c|c|c|}
\hline \multicolumn{4}{|c|}{ Bayes. } \\
\hline \multirow{3}{*}{$\begin{array}{l}\text { Kelas } \\
\text { sebenarnya }\end{array}$} & & $\begin{array}{c}\text { Prediksi } \\
\text { Malicious }\end{array}$ & Non-malicious \\
\hline & Malicious & 362 & 65 \\
\hline & Non-maicious & 7 & 493 \\
\hline
\end{tabular}

Tabel 3. Hasil klasifikasi dari dataset training dengan Decision Tree.

\begin{tabular}{|c|c|c|c|}
\hline \multirow{4}{*}{$\begin{array}{l}\text { Kelas } \\
\text { sebenarnya }\end{array}$} & \multicolumn{3}{|c|}{ Prediksi } \\
\hline & & icious & Non-malicious \\
\hline & Malicious & 427 & 0 \\
\hline & Non-maicious & 36 & 464 \\
\hline
\end{tabular}

Tabel 4. Hasil klasifikasi dari dataset testing dengan Multinomial Naïve Bayes.

\begin{tabular}{|c|c|c|c|}
\hline \multirow{3}{*}{$\begin{array}{l}\text { Kelas } \\
\text { sebenarnya }\end{array}$} & & $\begin{array}{l}\text { rediks } \\
\text { icious }\end{array}$ & Non-malicious \\
\hline & Malicious & 181 & 37 \\
\hline & Non-maicious & 36 & 464 \\
\hline
\end{tabular}

Tabel 5. Hasil klasifikasi dari dataset testing dengan Decision Tree.

\begin{tabular}{|c|c|c|c|}
\hline \multirow{3}{*}{$\begin{array}{l}\text { Kelas } \\
\text { sebenarnya }\end{array}$} & \multicolumn{3}{|c|}{$\begin{array}{c}\text { Prediksi } \\
\text { Malicious }\end{array}$} \\
\hline & Malicious & 212 & 6 \\
\hline & Non-maicious & 81 & 419 \\
\hline
\end{tabular}

3) Hasil Skenario III: Uji coba tahap testing dengan Multinomial Naive Bayes.

Hasil uji coba skenario ketiga ditunjukkan oleh Tabel 4. Dari 218 file malicious, 181 file terklasifikasi dengan benar namun 37 lainnya terklasifikasi sebagai non-malicious. Sedangkan dari 500 file non-malicious, 464 file terklasifikasi dengan benar tetapi 36 lainnya terklasifikasi sebagai malicious. Nilai precision dari hasil di atas adalah $83,41 \%(181 /(181+36))$ dan nilai recall-nya adalah $83,03 \%(181 / 218)$.

4) Hasil Skenario III: Uji coba tahap testing dengan Multinomial Naive Bayes.

Hasil uji coba skenario kelima ditunjukkan oleh Tabel 5. Dari 218 file malicious, 212 file terklasifikasi dengan benar namun 6 lainnya terklasifikasi sebagai non-malicious. Sedangkan dari 500 file non-malicious, 419 file terklasifikasi dengan benar tetapi 81 lainnya terklasifikasi sebagai malicious. Nilai precision dari hasil di atas adalah 72,35\% (212/(212+81)) dan nilai recall-nya adalah $97,24 \%$ (212/218).

\section{Evaluasi Hasil}

Dapat dilihat bahwa ternyata hasil klasifikasi menggunakan classifier Multinomial Naive Bayes cenderung lebih presisi dibandingkan classifier Decision Tree. Namun jumlah file malware yang dapat dideteksi oleh Multinomial Naive Bayes lebih sedikit daripada Decision Tree.

Kedua classifier tersebut memiliki performa yang cukup baik untuk mendeteksi kode sumber malicious, namun dalam kasus-kasus berbeda, salah satu classifier akan lebih baik daripada classifier yang lain. Misalnya apabila pendeteksian malware ingin dijalankan secara otomatis pada lingkungan 
aplikasi web yang menggunakan kerangka kerja luar atau sistem manajemen konten seperti Wordpress, akan lebih baik apabila menggunakan classifier Multinomial Naive Bayes. Dengan Multinomial Naive Bayes, kemungkinan file-file non-malware krusial terdeteksi sebagai malware lebih kecil dibandingkan dengan menggunakan Decision Tree. Sedangkan Decision Tree dapat digunakan apabila pengguna tidak terlalu mempermasalahkan kesalahan klasifikasi terhadap file-file non-malicious dan ingin memaksimalkan kemampuan pendeteksian kode malicious.

\section{KESIMPULAN}

Berdasarkan perancangan, implementasi, dan pengujian terhadap aplikasi yang dibuat, dapat diambil kesimpulan sebagai berikut:

1. Pendeteksian kode malicious dalam lingkungan aplikasi web berbasis PHP telah dilakukan dengan menerapkan teknik kategorisasi dokumen. Yakni dengan melakukan tokenisasi (mengambil nama variabel, fungsi, kelas, keyword eval dan echo, serta konstanta string), membuat model classifier, dan menggunakan model classifier tersebut untuk mengklasifikasi file-file lain.

2. Dari hasil uji coba dengan 218 file malicious dan 500 file non-malicious didapat bahwa Multinomial Naive Bayes dapat mengklasifikasi dengan tingkat precision sebesar $83 \%$ dan recall sebesar $83 \%$. Sedangkan model Decision Tree dapat mengklasifikasi dengan tingkat precision sebesar $72 \%$ dan recall hingga $97 \%$. Model classifier Multinomial Naive Bayes cenderung lebih presisi daripada Decision Tree, namun Decision Tree dapat lebih banyak mendeteksi file-file malicious.

\section{SARAN}

Beberapa saran yang dapat diberikan untuk pengembangan dari topik yang dibahas pada makalah ini adalah sebagai berikut:

1. Tambahkan jenis kode sumber dari aplikasi selain berbasis Wordpress ke dalam dataset training dan testing. Hal ini dapat dilakukan untuk mengetahui performa teknik kategorisasi dokumen untuk mendeteksi malware pada aplikasi-aplikasi web jenis lain.

2. Tambahkan jenis malware selain web shell ke dalam dataset training dan testing. Hal ini dapat dilakukan untuk mengetahui performa teknik kategorisasi dokumen untuk mendeteksi malware-malware jenis lain.

3. Gunakan metode-metode seleksi fitur dan/atau reduksi dimensionalitas seperti Principal Component Analysis sebelum membangun model classifier. Karena tiap-tiap jenis token dihitung sebagai satu fitur, maka masing-masing dokumen pada kasus kategorisasi dokumen memiliki banyak fitur. Dari hasil uji coba yang dilakukan diketahui bahwa satu dokumen (satu file kode sumber) memiliki lebih dari 14 ribu fitur. Pada beberapa metode machine learning seperti Decision Tree, jumlah fitur yang jauh melebihi jumlah sampel/dokumen akan menyebabkan overfitting [6]. Oleh karena itu reduksi dimensionalitas atau seleksi fitur dapat diterapkan untuk mengetahui pengaruhnya terhadap model classifier yang dihasilkan.
4. Lakukan uji coba kategorisasi dokumen dengan menggunakan algoritma machine learning selain Decision Tree dan Mutinomial Naive Bayes. Algoritma-algoritma tersebut dapat diterapkan dan dibandingkan performanya dengan algoritma algoritma yang telah diterapkan pada makalah ini.

\section{DAFTAR PUSTAKA}

[1] Clint Feher Asaf Shabtai, Robert Moskovitch and Shlomi Dolev. Detecting unknown malicious code by applying classification techniques on opcode patterns. Security Informatics. doi: 10.1186/2190-8532-1-1.

[2] Fabrizio Sebastiani. Machine learning in automated text categorization. ACM Comput. Surv., 34(1):1-47, March 2002. ISSN 0360-0300. doi: $10.1145 / 505282.505283$.

[3] G. Salton, A. Wong, and C. S. Yang. A vector space model for automatic indexing. Commun. ACM, 18(11):613-620, November 1975. ISSN 0001-0782. doi: 10.1145/361219.361220.

[4] Harry Zhang. The optimality of Naive Bayes. In Valerie Barr and Zdravko Markov, editors, Proceedings of the Seventeenth International Florida Artificial Intelligence Research Society

[5] Christopher D. Manning, Prabhakar Raghavan, and Hinrich Schütze. Introduction to Information Retrieval. Cambridge University Press, New York, NY, USA, 2008. ISBN 0521865719, 9780521865715.

[6] Decision trees. http://scikit-learn.org/stable/modules/tree.html. Diakses: 2016-12-24.

[7] L. Breiman, J. Friedman, R. Olshen, and C. Stone. Classification and Regression Trees. Wadsworth, Belmont, CA, 1984. 